\title{
Tumor Necrosis Factor Receptor Superfamily, Member 1B Haplotypes Increase or Decrease the Risk of Inflammatory Bowel Diseases in a New Zealand Caucasian Population
}

\author{
Lynnette R. Ferguson, ${ }^{1,2}$ Dug Yeo Han, ${ }^{1,2}$ Claudia Huebner, ${ }^{1,2}$ Ivonne Petermann,, 2 \\ Murray L. Barclay, ${ }^{3,4}$ Richard B. Gearry,, ${ }^{3,4}$ Alan McCulloch, ${ }^{2,5}$ and Pieter S. Demmers ${ }^{2,6}$ \\ ${ }^{1}$ Discipline of Nutrition, The University of Auckland, Private Bag 92019, Auckland 1023, New Zealand \\ ${ }^{2}$ Nutrigenomics New Zealand, New Zealand \\ ${ }^{3}$ Department of Gastroenterology, Christchurch Hospital, Christchurch 8011, New Zealand \\ ${ }^{4}$ Department of Medicine, University of Otago Christchurch, New Zealand \\ ${ }^{5}$ Crop and Food Research, Mosgiel 9053, New Zealand \\ ${ }^{6}$ AgResearch Limited, Mosgiel 9053, New Zealand
}

Correspondence should be addressed to Lynnette R. Ferguson, 1.ferguson@auckland.ac.nz

Received 3 October 2008; Accepted 2 February 2009

Recommended by Robert Wyllie

Inflammatory bowel diseases (IBDs) comprising Crohn disease (CD) and ulcerative colitis (UC) are chronic inflammatory conditions with polygenic susceptibility. Interactions between TNF-alpha and TNF-alpha receptor play a fundamental role in inflammatory response. This study investigates the role that selected single nucleotide polymorphisms (SNPs) and haplotypes in the TNF-alpha receptor (TNSFRSF1B) gene play in the risk of IBD in a New Zealand Caucasian population. DNA samples from 388 CD, 405 UC, 27 indeterminate colitis patients, and 293 randomly selected controls, from Canterbury, New Zealand were screened for 3 common SNPs in TNSFRSF1B: rs1061622 (c.676T > C), rs1061624 (c. ${ }^{*} 1663 \mathrm{~A}>\mathrm{G}$ ), and rs3397 (c.*1690T > C), using TaqMan technologies. Carrying the rs 1061624 variant decreased the risk of UC in the left colon $(\mathrm{OR} 0.73,95 \% \mathrm{CI}=0.54-$ 1.00 ) and of being a smoker at diagnosis (OR 0.62; 95\% CI $=0.40-0.96)$. Carrying the rs3397 variant decreased the risk of penetrating $\mathrm{CD}(\mathrm{OR} 0.62,95 \% \mathrm{CI}=0.40-0.95)$. Three marker haplotype analyses revealed highly significant differences between CD patients and control subjects $\left(\chi^{2}=29.9, \mathrm{df}=7, P=.0001\right)$ and $\mathrm{UC}$ cases and controls $\left(\chi^{2}=46.3, \mathrm{df}=7, P<.0001\right)$. We conclude that carrying a 3-marker haplotype in the TNSFRSF1B gene may increase (e.g., haplotype of GGC was 2.9-fold more in the CD or UCpatients) or decrease (e.g., TGT was 0.47 -fold less in UC patients) the risk of IBD in a New Zealand Caucasian population.

Copyright ( $) 2009$ Lynnette R. Ferguson et al. This is an open access article distributed under the Creative Commons Attribution License, which permits unrestricted use, distribution, and reproduction in any medium, provided the original work is properly cited.

\section{Introduction}

Inflammatory bowel diseases (IBDs), including Crohn disease (CD) and ulcerative colitis (UC), provide a good example of a disorder for which there is compelling evidence for genetically determined susceptibility that interacts with environmental factors, including microbiota and diet [1]. It is clear that there are strong ethnic differences in IBD susceptibility, and that different populations may have varying levels of genetic involvement, with distinctive risk alleles [2].
For example, although there is a very low incidence of CD in Bangladesh, the children of Bangladesh immigrants to the UK show a very high incidence of the disease [2]. As recently as 2005 , it seemed that a maximum of 10-12 genetic loci could be involved in disease susceptibility [3], but whole genome association studies have changed the landscape such that a more recent meta-analysis [4] suggested involvement of more than 30 different loci. It becomes important to establish which loci are relevant to individual population groups living in specific locations. 
TABLE 1: TNFRSF1B polymorphisms tested in the Canterbury population.

\begin{tabular}{|c|c|c|c|c|c|}
\hline rs number & Location & Nucleotide change & $\begin{array}{l}\text { Amino acid } \\
\text { position }\end{array}$ & $\begin{array}{l}\text { Major allele } \\
\text { in Europeans }\end{array}$ & $\begin{array}{l}\text { Frequency in other European } \\
\text { groups }\end{array}$ \\
\hline rs. 1061622 & Exon 6 (nonsynonymous) & c. $676 \mathrm{~T}>\mathrm{G}$ & 196 & $\mathrm{~T}$ & $75 \%$ [Hapmap] 80.2\% [Wachke] \\
\hline rs. 1061624 & Exon $103^{\prime}$ UTR & c. ${ }^{*} 1663 \mathrm{~A}>\mathrm{G}$ & & A & 51.7\% [Hapmap] 55.2\% [Washke] \\
\hline rs.3397 & Exon $103^{\prime}$ UTR & c. ${ }^{*} 1690 \mathrm{~T}>\mathrm{C}$ & & $\mathrm{T}$ & $52.6 \%[$ Hapmap] \\
\hline
\end{tabular}

The prevalence and incidence of IBD in New Zealand are believed to have increased substantially in recent years, although stringently collated data are not available prior to 2004 [5]. As at 1 June 2005, Gearry et al. (2006) reported a prevalence of IBD in Canterbury, New Zealand, as 308.3 per 100000 subjects ( 155.2 with CD and 145 with UC per 100000$)$. Although we have previously associated polymorphisms in several genes including NOD1\&2, TLR4, DLG5, ATG16L1, and IL23R with risk of IBD in New Zealand [6-12], these only increase the IBD risk to a small extent and cannot explain the high New Zealand disease incidence. For example, carrying the common NOD2 1007-femtdsecond mutation increased the risk of CD 4.4 fold ( $95 \%$ confidence interval 1.6-12) [12].

Tumor necrosis factor-alpha (TNF- $\alpha$ ) is a proinflammatory cytokine that plays a central role in IBD pathogenesis [8]. An inhibitor of TNF- $\alpha$, infliximab (IFB), is an effective treatment of moderate to severe IBD, and polymorphisms in the TNF- $\alpha$ gene not only affect the phenotype of IBD, but may also impact IFB susceptibility [8, 13]. However, TNF- $\alpha$ does not work independently in the cell, but acts through binding to two receptors, TNF receptor superfamily, member 1A (TNFRSF1A or p55/p60) and TNF receptor superfamily, member 1B (TNFRSF1B, also called TNFR, $\mathrm{p} 75 / \mathrm{p} 80)$. TNFRSF1B is the larger of these receptors, being present on many cell types, and strongly expressed on stimulated $\mathrm{T}$ and B lymphocytes [14]. There is evidence that it regulates the binding of TNF- $\alpha$ to TNFRSF1A, and thus may regulate the levels of TNF- $\alpha$ necessary to stimulate the action of the transcription factor, nuclear factor-kappa $\mathrm{B}$ (NF-kB) [15]. The gene for TNFRSF1B is located on chromosome 1p36.3-p36.2 [16-18], which coincides with the previously identified IBD susceptibility locus, IBD7 [19].

Single nucleotide polymorphisms (SNPs) in TNFRSF1B have been suggested to modulate the risk of a number of autoimmune diseases, including rheumatoid arthritis, systemic lupus erythematosus, and CD [20-24]. This study considers the role of three SNPs in TNFRSF1B Table 1 on the overall risk or phenotype of IBD in a New Zealand Caucasian population, recruited from the Canterbury region in New Zealand [5] 2006. These SNPs were previously associated with CD risk in other populations $[22,23]$.

\section{Materials and Methods}

2.1. Study Participants. The cases in this study are a random subset of the Caucasian participants of the Canterbury Inflammatory Bowel Disease Project, which has been described in detail elsewhere [5]. All subjects consented to collection of peripheral blood for DNA extraction and genotyping. Phenotypic characteristics of this cohort are described in more detail by Tarrant et al. [25]. The database included their clinical diagnosis and IBD phenotype as defined using standard diagnostic criteria and using the Montreal Classification system [26]. The Montreal classification was current as of 1 June 2005.

388 CD participants, 403 UC participants, and 27 indeterminate colitis (IC) participants were genotyped for this study, as described in Table 2. All participants selfreported European ancestry, and patients who self-reported having any Maori or other non-Caucasian ancestry are not included.

The New Zealand Caucasian controls $(n=293)$ were selected at random from the electoral roll, comprising $93 \%$ of the population over eighteen years of age in Canterbury, New Zealand [27].

2.2. Applied Biosystems TaqMan SNP Genotyping Assay. SNPs were genotyped using the TaqMan MGB diallelic discrimination system. Probes and oligonucleotides were obtained from Applied Biosystems using the Assay-byDesign product (listed in Table 3). For the marker c.676T $>\mathrm{C}$ (rs1061622) a predesigned SNP genotyping assay was available (C_8861232_20). The reactions were prepared by using $2 x$ TaqMan Universal Master Mix, 40x SNP Genotyping Assay Mix, DNase-free water, 10 ng genomic DNA in a final volume of $5 \mathrm{uL}$ per reaction. The PCR amplification was performed using the ABI Prism $7900 \mathrm{HT}$ sequencedetector machine under the following conditions: 10 minutes $95^{\circ} \mathrm{C}$ enzyme activation followed by 40 cycles at $92^{\circ} \mathrm{C}$ for 15 seconds and $60^{\circ} \mathrm{C}$ for 1 minute (annealing/extension). The allelic discrimination results were determined after the amplification by performing an endpoint read. To estimate genotype accuracy approximately $5 \%$ of the samples, that is, 70 cases were genotyped in duplicate or triplicate for each of the markers. No conflicted duplicate genotypes were detected.

2.2.1. Statistical Analysis. The allelic trend test [26] and Fisher's exact genotypic test were used to compare case and control allele frequencies. An exact test was used to test for departures from Hardy-Weinberg equilibrium (HWE) in the case and the control samples [27]. Allelic odds ratios were calculated and confidence intervals for the allelic odds ratio were also calculated under the assumption of HWE in the cases and the control groups. Logistic regression analysis was used to examine the relationship between genotypes 
TABLE 2: Summary of clinical and demographic data for the set of Caucasian IBD patients.

\begin{tabular}{|c|c|c|c|c|}
\hline & & $\mathrm{CD} n(\%)$ & $\mathrm{UC} n(\%)$ & IC $n(\%)$ \\
\hline \multicolumn{5}{|l|}{ Gender } \\
\hline Female & & $249(64.2)$ & $214(52.8)$ & $15(55.6)$ \\
\hline Male & & $139(35.8)$ & $191(47.2)$ & $12(44.4)$ \\
\hline \multicolumn{5}{|l|}{ Age at first diagnosis } \\
\hline Below 17 & & $39(10.0)$ & $26(6.4)$ & 0 \\
\hline Between 17 and 40 & & $199(51.3)$ & $184(45.4)$ & $15(55.6)$ \\
\hline Above 40 & & $150(38.7)$ & $195(48.2)$ & $12(44.4)$ \\
\hline \multicolumn{5}{|l|}{ CD location } \\
\hline Ileal & & $125(32.2)$ & & \\
\hline Colonic & & $169(43.6)$ & & \\
\hline Ileocolonic & & $90(23.2)$ & & \\
\hline Unknown $(\mathrm{U}+\mathrm{UN})$ & & $4(1.0)$ & & \\
\hline \multicolumn{5}{|l|}{ UC location } \\
\hline Proctitis & & & $140(34.6)$ & $3(11.1)$ \\
\hline Left colon & & & $107(26.4)$ & $5(18.5)$ \\
\hline Pancolitis & & & $154(38.0)$ & $19(70.4)$ \\
\hline Unknown & & & $4(1.0)$ & 0 \\
\hline \multicolumn{5}{|l|}{ Behaviour } \\
\hline \multirow[t]{2}{*}{ Nonstricturing, nonpenetrating perianal disease: } & With & $47(21.5)$ & & \\
\hline & Without & $172(78.5)$ & & \\
\hline \multirow[t]{2}{*}{ Stricturing perianal disease: } & With & $46(38.0)$ & & \\
\hline & Without & $75(62.0)$ & & \\
\hline \multirow[t]{2}{*}{ Penetrating perianal disease: } & With & $17(35.4)$ & & \\
\hline & Without & $31(64.6)$ & & \\
\hline Any relative with IBD: Yes $(n=143)$ & & $74(19.1)$ & $65(16.1)$ & $5(18.5)$ \\
\hline Bowel resection: Yes $(n=214)$ & & $142(36.6)$ & $70(17.3)$ & $2(7.4)$ \\
\hline Smoker at diagnosis: Yes $(n=147)$ & & $97(25.7)$ & $49(12.3)$ & $2(7.7)$ \\
\hline Ever used immunomodulators: Yes $(n=296)$ & & $203(52.3)$ & $86(21.2)$ & $8(29.6)$ \\
\hline Extraintestinal manifestations: Yes $(n=142)$ & & $75(19.3)$ & $64(15.8)$ & $3(11.1)$ \\
\hline
\end{tabular}

TABLE 3: Primer and probe sequences for custom-made TaqMan SNP genotyping assay for TNFRSF1B.

\begin{tabular}{|c|c|}
\hline TaqMan SNP genotyping assay & DNA sequence \\
\hline TNFRSF1B ${ }_{-}^{*} 1663 \mathrm{~A}>\mathrm{G}$ forward primer & 5' TGACCTGCAGGCCAAGAG 3' \\
\hline TNFRSF1B_*1663A > G_reverse primer & 5' CCATGGCAGCAGAGGCTTT 3' \\
\hline TNFRSF1B_ ${ }^{*} 1663 \mathrm{~A}>$ G_VIC probe & $5^{\prime}$ CCACAACTCGCTGCC $3^{\prime}$ \\
\hline TNFRSF1B_* $1663 \mathrm{~A}>$ G_FAM probe & $5^{\prime}$ CACAACCCGCTGCC $3^{\prime}$ \\
\hline TNFRSF1B_*1690T > C_forward primer & $5^{\prime}$ TGACCTGCAGGCCAAGAG $3^{\prime}$ \\
\hline TNFRSF1B_* $1690 \mathrm{~T}$ > C_reverse primer & $5^{\prime}$ CCATGGCAGCAGAGGCTTT $3{ }^{\prime}$ \\
\hline TNFRSF1B_*1690T > C_VIC probe & $5^{\prime}$ CATGGCGTGTCCC $3^{\prime}$ \\
\hline TNFRSF1B_*1690T > C_FAM probe & $5^{\prime}$ CCATGGTGTGTCCC $3^{\prime}$ \\
\hline
\end{tabular}

and disease of CD, UC, and IBD using SAS (V9.1 SAS Institute., Cary, NC, USA). Haplotype analysis was carried out using haplo.stats in $\mathrm{R}[28]$ to test associations between haplotypes and traits. We also performed an exploratory analysis of allele frequency differences between controls and patient subgroups using the clinical characteristics given in Table 2 .

\section{Results}

No significant deviation from Hardy-Weinberg Equilibrium was found in the control group for all three SNPs. For each of the polymorphisms studied, the risks of carrying the variant was compared CD and UC patients with the control group, as shown in Tables 4 and 5. There was no significant difference 


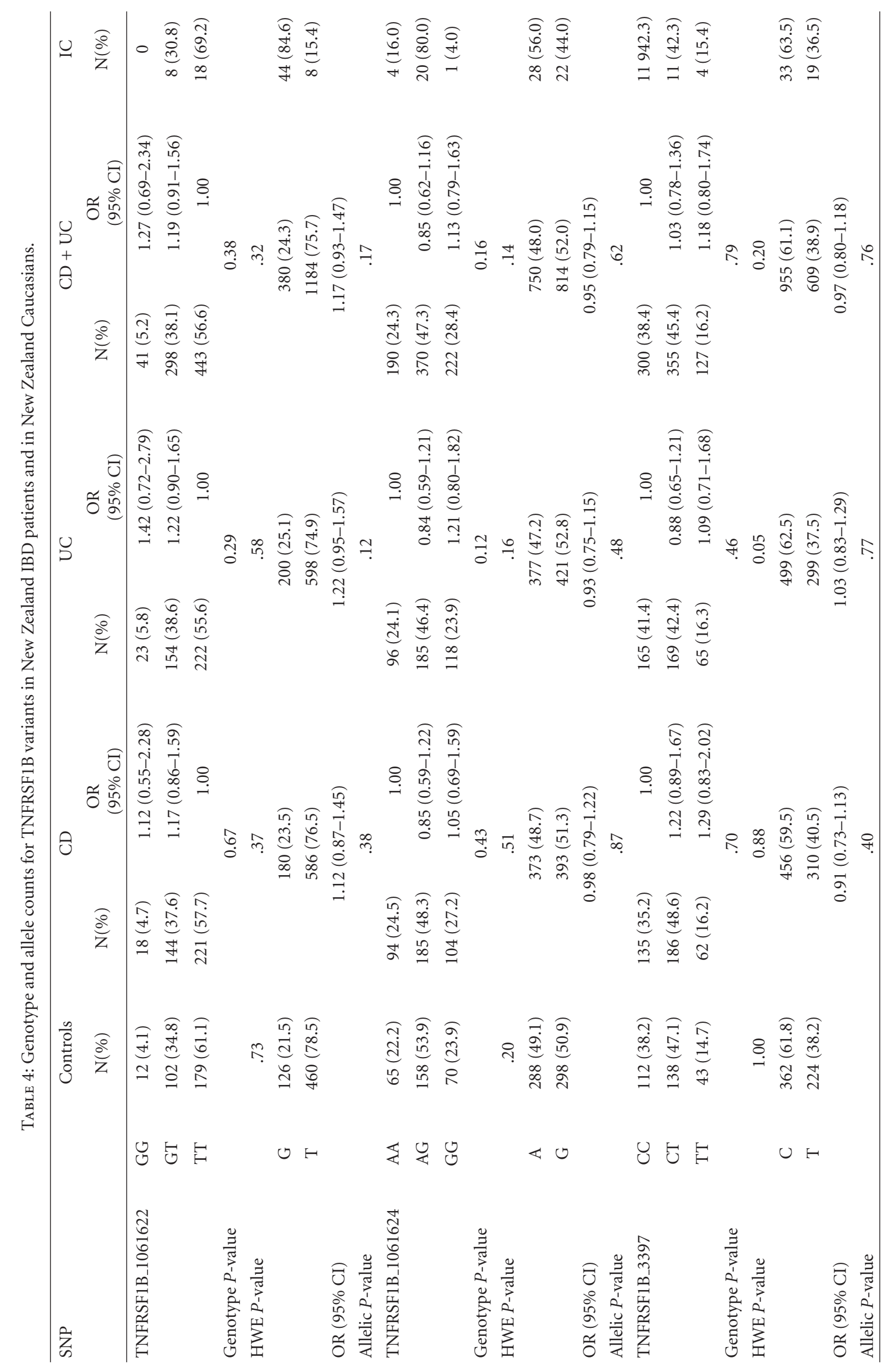




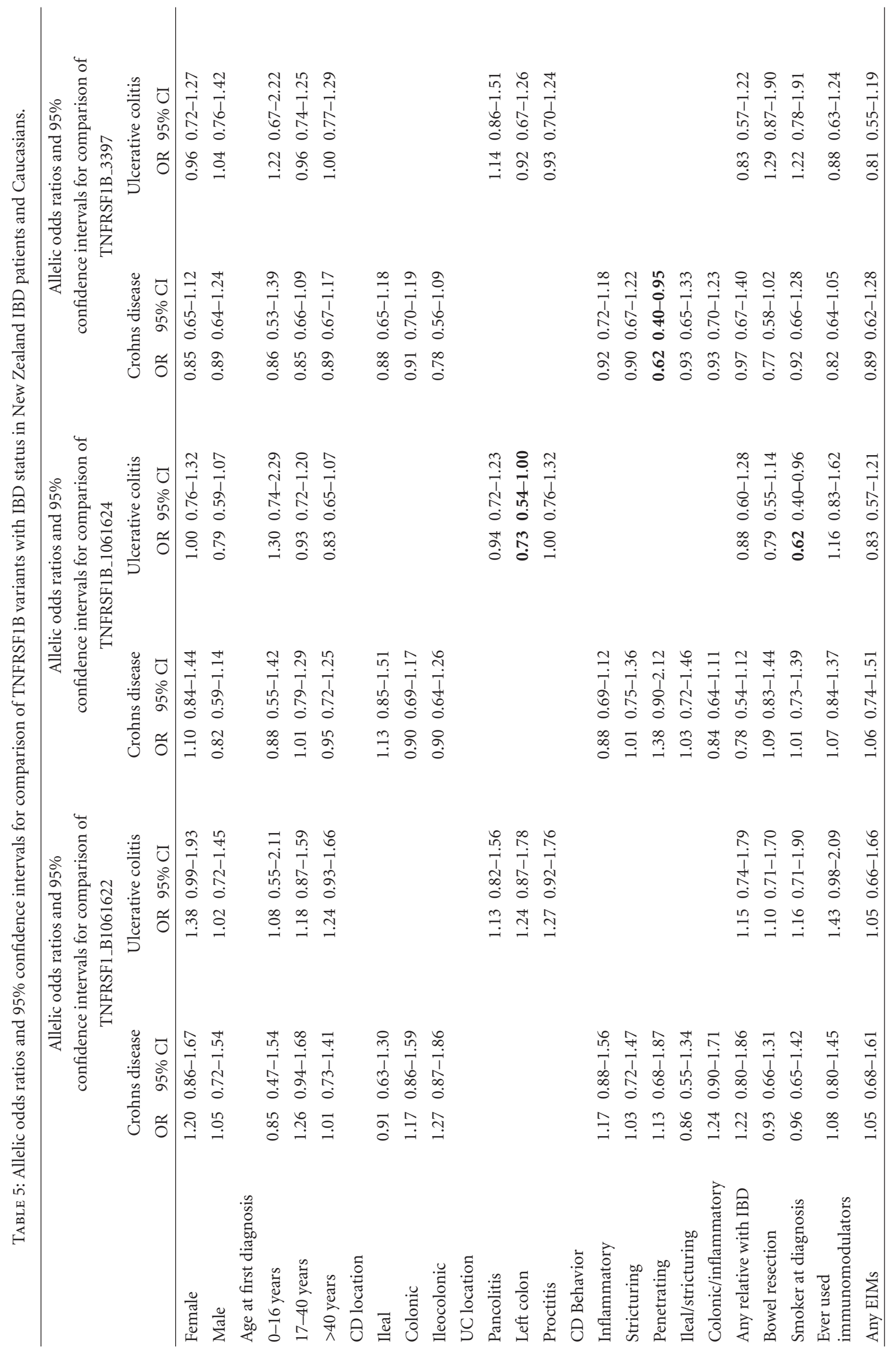


TABLE 6: Haplotype analysis of three-SNP TNFRSF1B haplotype in IBD status in New Zealand IBD patients and Caucasians.

\begin{tabular}{|c|c|c|c|c|c|c|c|}
\hline & Haplotype & Case frequency & Control frequency & Hap frequency & Hap-score & $P$-value & $\begin{array}{l}\text { Global score } \\
\text { statistics }\end{array}$ \\
\hline \multirow[t]{9}{*}{$\mathrm{CD}$} & $\begin{array}{l}\text { Three SNPs TNFRSF1B region } \\
\text { (rs1061622, rs1061624, rs3397) }\end{array}$ & & & & & & \multirow{9}{*}{$\begin{array}{l}\chi^{2}=29.9 \\
\mathrm{df}=7 \\
P=.0001\end{array}$} \\
\hline & GAC & 0.057 & 0.101 & 0.075 & -1.55 & .12 & \\
\hline & GAT & 0.048 & 0.050 & 0.051 & 0.09 & .93 & \\
\hline & GGC & 0.091 & 0.031 & 0.064 & 2.78 & .005 & \\
\hline & GGT & 0.039 & 0.033 & 0.036 & 0.77 & .44 & \\
\hline & TAC & 0.210 & 0.277 & 0.241 & -1.88 & .06 & \\
\hline & TAT & 0.172 & 0.064 & 0.122 & 3.29 & .001 & \\
\hline & TGC & 0.238 & 0.209 & 0.224 & 0.16 & .88 & \\
\hline & TGT & 0.145 & 0.236 & 0.186 & -1.90 & .06 & \\
\hline \multirow[t]{9}{*}{$\mathrm{UC}$} & $\begin{array}{l}\text { Three SNPs TNFRSF1B region } \\
\text { (rs1061622, rs1061624, rs3397) }\end{array}$ & & & & & & \multirow{9}{*}{$\begin{array}{l}\chi^{2}=46.3 \\
\mathrm{df}=7 \\
P<.0001\end{array}$} \\
\hline & GAC & 0.067 & 0.101 & 0.078 & -0.92 & .36 & \\
\hline & GAT & 0.057 & 0.050 & 0.056 & 0.43 & .67 & \\
\hline & GGC & 0.091 & 0.031 & 0.067 & 3.32 & $<.0001$ & \\
\hline & GGT & 0.036 & 0.033 & 0.034 & 0.63 & .53 & \\
\hline & TAC & 0.179 & 0.277 & 0.278 & -2.81 & .005 & \\
\hline & TAT & 0.170 & 0.064 & 0.128 & 2.76 & .006 & \\
\hline & TGC & 0.289 & 0.209 & 0.259 & 1.75 & .08 & \\
\hline & TGT & 0.112 & 0.236 & 0.159 & -3.40 & .0007 & \\
\hline
\end{tabular}

in the allele frequencies of the TNFRSF1B rs1061622, rs1061624, and rs3397 variants between CD or UC patients and healthy control subjects.

Individuals carrying the rs1061622 variant showed no significant differences from those carrying the reference allele (the $\mathrm{G}$ allele), for overall risk of IBD or for any phenotypic class. No significant differences found any of the age at first diagnosis, any location of $\mathrm{CD}$ and $\mathrm{UC}$, or $\mathrm{CD}$ behavior. Having any relatives with IBD, bowel resection, smoke at diagnosis, ever used immunomodulators, or any EIMs were not significanty different between CD or UC patients and controls.

For the rs1061624 variant, those individuals carrying the A allele had a decreased probability of developing UC located in the left colon $(\mathrm{OR}=0.73,95 \% \mathrm{CI}=0.54-1.00, P=.05)$. Carrying the A allele also reduced the probability of UC patients having smoked at diagnosis $(\mathrm{OR}=0.62,95 \% \mathrm{CI}$ $=0.40-0.96, P=.03$ ) but showed no statistically significant effects in patterns of CD disease risk.

Those individuals carrying the variant TNFRSF1B rs3397 $C$ allele showed a statistically significant reduction in the probability of developing CD with penetrating behavior, as compared with those carrying the $\mathrm{T}$ allele $(\mathrm{OR}=0.62,95 \%$ $\mathrm{CI}=0.40-0.95, P=.03)$. No other phenotypes showed significant effects in patterns of disease risk of CD. For UC patients, those individuals carrying the variant rs3397 C allele showed no statistically significant effects in patterns of IBD (Table 4).

3.1. Haplotype Analysis. Table 6 summarizes the results of haplotype analysis of the three TNFRSF1B SNPs (rs1061622, rs1061624, and rs3397). Haplotype frequencies were estimated, and association analyses were performed with respect to CD and UC in New Zealand IBD patients and Caucasian controls. A score for each haplotype (Hap-score) was calculated and $P$-value also calculated for the significance of each Hap-score. A positive hap-score implies that the haplotype occurs more frequently in the CD or UC case group than control subjects. A global $P$-value tests the overall association between haplotypes and the response.

There was a significant difference between these haplotypes for CD patients and control subjects $\left(\chi^{2}=29.9\right.$, df $=7, P=.0001$ ). In the three SNPs (rs1061622, rs1061624, and rs3397) in CD, the frequencies of haplotypes of GGC (9.1\% for case versus $3.1 \%$ for control group, $P=.005$ ) and TAT $(17.2 \%$ versus $6.4 \%, P=.001)$ were significantly different, with haplotypes GGC and TAT occurring more in $\mathrm{CD}$ cases than the control group. TAC $(21.0 \%$ versus $27.7 \%, P=.06)$ and TGT $(14.5 \%$ versus $23.6 \%, P=.06)$ were marginally significantly different between case and control groups, occurring less frequently in the cases. Haplotype TAC was the most common, with Hap-frequencies of $24.1 \%$. Haplotype GGT was the most uncommon in CD case $(3.9 \%)$ and control (3.3\%) subjects, but occurred at equal frequencies in both (Hap-frequencies of $3.6 \%$, $P>$.05). Haplotypes GAC, GAT, and TGC occurred at equal frequencies in $\mathrm{CD}$ patients and control subjects $(P>$ $.05)$.

There were also significant associations between these haplotypes for UC cases as compared with control subjects $\left(\chi^{2}=46.3, \mathrm{df}=7, P<.0001\right)$. For the three marker haplotypes (rs1061622, rs1061624, and rs3397), 
the frequencies of haplotypes of GGC (9.1\% versus 3.1\%, $P<.0001)$, TAC $(17.9 \%$ versus $27.7 \%, P=.005)$, TAT (17.0\% versus $6.4 \%, P=.006)$, and TGT $(11.2 \%$ versus $23.6 \%, P=.0007)$ were significantly different between case and control subjects. Haplotype TAC was the most common in UC cases (Hap-frequency of $27.8 \%, P=.005$ ), whereas haplotype GGT was the most uncommon in UC patients and control subjects, with frequencies of $3.6 \%$ and $3.3 \%$, respectively (Hap-frequency $=3.4 \%, P=.53$ ). The frequencies of GAC and TGC were lower and the frequency of GAT higher in UC patients than control subjects, but there was no statistically significant difference between them.

\section{Discussion}

The present results show that carrying a single variant allele in TNFRSF1B c.676T > C, 1663A > G, or 1690T > C has no significant effect on the overall risk of either $\mathrm{CD}$ or UC. However, the risk of certain phenotypes is affected by either of the latter two variant alleles. More striking, however, is the effect of carrying certain haplotypes, and specific combinations may either increase or decrease the risk of either CD or UC in the New Zealand Caucasian population, with strong statistical significance.

TNFRSF1B is the main TNF receptor found on circulating $\mathrm{T}$ cells [14]. The gene contains 10 exons, spanning around $26 \mathrm{~kb}$ of genomic DNA and encoding 415 amino acids [14]. Cysteine-rich extracellular regions, comprising three to six disulfide-linked domains, are considered to be important for ligand binding and are expressed by several different cell types [29]. The protein produced by the gene forms a heterocomplex with the product of TNFRSF1A, leading to recruitment of two antiapoptotic proteins cIAP1 and c-IAP2, both of which possess E3 ubiquitin ligase activity. c-IAP1 has been suggested to potentiate TNF-a induced apoptosis through the ubiquitination and degradation of TNF-receptor-associated factor 2, which produces antiapoptotic signals. We have previously shown that TNF-alpha polymorphisms may contribute significantly to the risk of certain IBD phenotypes in the New Zealand population [9]. The present data augment the previous conclusion, that variant alleles associated with this pathway are important for IBD risk in this population.

There are limited data on the functionality of the various SNPs in this gene. However, the $676 \mathrm{~T}>\mathrm{G}$ polymorphism replaces a methionine by an arginine, and is functional, as the cytotoxic activity is increased [30]. The variant polymorphism has been previously associated with susceptibility to familial rheumatoid arthritis (RA) [20] and systemic lupus erythematosus (SLE) [21]. However, association studies have suggested that the other SNPs considered in the present study might be in linkage with a functional SNP, even if not themselves functional [22, 23, 31]. Perhaps even more relevant to patients with IBD is that associations have recently been demonstrated between a two allele haplotypes and responses to IFB in Japanese CD patients $[28,32]$.
Kawasaki et al. [31] reported no association between the variant SNP at position 676 and the risk of either form of IBD in their Japanese database. These data are consistent with our own findings in the present study. However, these data do not agree with other observations in a European Caucasian population [23] which associated TNFRSF1B with clinical CD phenotypes. They studied a well-phenotyped cohort of 205 patients with CD and 106 controls to associate the variant SNP at this position with increased risk of $\mathrm{CD}$ $(P=.034)$, but decreased risk with UC or with the need for surgery. We suggest that the previous European consortium data had insufficient power to conclusively decide a negative result.

It is of some interest that we have associated differences in the risk of certain IBD phenotypes with variant alleles in the other two SNPs considered (1663A > G, or 1690T > C). A Japanese study considered 124 patients with CD, 106 patients with UC, and 111 unrelated healthy controls [22] for these same two SNPs, while Waschke et al. [23] studied the first but not the second in their European Caucasian group. Neither of these previous reports demonstrated a statistically significant difference in carrying either of the variant alleles. We note, however, that in the Japanese population but not in European groups [23], C appears to be the major allele at position 1493.

Although Sashio et al. [22] reported only minor effects on IBD risk associated with carrying any single variant allele, they found a significant difference (odds ratio of 2.13) in carrier frequency for haplotype AT (1466A, 1493T) between CD patients and the controls. These differences were most significant in CD patients with either internal or external fistula, and/or who responded poorly to nutritional, medical, or surgical therapy. Similar haplotype effects are recorded in the present study. However, we are currently unable to find a convincing explanation of the converse data for UC.

Although the region containing this gene has not emerged from recent whole genome association studies as a lead candidate in CD (WTCCC, 2007; Barrett et al. 2008) it is of interest that two of the genes consistently appearing important are closely related to the present gene. The protein product of TNFAIP3 (TNF-alpha- induced protein 3) inhibits TNF-alpha-induced NFkB-dependent gene expression by interfering with transactivation signals. Markers with lower levels of significance in these studies include one within TNFSF15 (tumour necrosis factor superfamily, member 15). Taken together, the present data add support to an important role for TNF-alpha and related molecules in CD susceptibility and progression.

\section{Acknowledgments}

The authors thank the Canterbury participants in our study. Other funding sources for the case and control DNA collection are the Canterbury Medical Research Foundation, Canterbury Liver and Digestive Diseases Trust, and Christchurch Gastroenterology Research Trust. Nutrigenomics New Zealand is a collaboration between AgResearch Ltd., Crop \& Food Research, HortResearch and The University of Auckland. The authors declare no conflicts of interest. 


\section{References}

[1] L. R. Ferguson, A. N. Shelling, B. L. Browning, C. Huebner, and I. Petermann, "Genes, diet and inflammatory bowel disease," Mutation Research/Fundamental and Molecular Mechanisms of Mutagenesis, vol. 622, no. 1-2, pp. 70-83, 2007.

[2] E. Tsironi, R. M. Feakins, C. S. Roberts, D. S. Rampton, and D. Phil, "Incidence of inflammatory bowel disease is rising and abdominal tuberculosis is falling in Bangladeshis in East London, United Kingdom," The American Journal of Gastroenterology, vol. 99, no. 9, pp. 1749-1755, 2004.

[3] S. Schreiber, P. Rosenstiel, M. Albrecht, J. Hampe, and M. Krawczak, "Genetics of Crohn disease, an archetypal inflammatory barrier disease," Nature Reviews Genetics, vol. 6, no. 5, pp. 376-388, 2005.

[4] J. C. Barrett, S. Hansoul, D. L. Nicolae, et al., "Genome-wide association defines more than 30 distinct susceptibility loci for Crohn's disease," Nature Genetics, vol. 40, no. 8, pp. 955-962, 2008.

[5] R. B. Gearry, A. Richardson, C. M. A. Frampton, et al., "High incidence of Crohn's disease in Canterbury, New Zealand: results of an epidemiologic study," Inflammatory Bowel Diseases, vol. 12, no. 10, pp. 936-943, 2006.

[6] B. L. Browning, C. Huebner, I. Petermann, et al., "Association of DLG5 variants with inflammatory bowel disease in the New Zealand Caucasian population and meta-analysis of the DLG5 R30Q variant," Inflammatory Bowel Diseases, vol. 13, no. 9, pp. 1069-1076, 2007.

[7] B. L. Browning, C. Huebner, I. Petermann, et al., "Has tolllike receptor 4 been prematurely dismissed as an inflammatory bowel disease gene? Association study combined with metaanalysis shows strong evidence for association," The American Journal of Gastroenterology, vol. 102, no. 11, pp. 2504-2512, 2007.

[8] L. R. Ferguson, B. L. Browning, C. Huebner, et al., "Single nucleotide polymorphisms in human Paneth cell defensin A5 may confer susceptibility to inflammatory bowel disease in a New Zealand Caucasian population," Digestive and Liver Disease, vol. 40, no. 9, pp. 723-730, 2008.

[9] L. R. Ferguson, C. Huebner, I. Petermann, et al., "Single nucleotide polymorphism in the tumor necrosis factor-alpha gene affects inflammatory bowel diseases risk," World Journal of Gastroenterology, vol. 14, no. 29, pp. 4652-4661, 2008.

[10] R. L. Roberts, R. B. Gearry, J. E. Hollis-Moffatt, et al., "IL23R R381Q and ATG16L1 T300A are strongly associated with Crohn's disease in a study of New Zealand Caucasians with inflammatory bowel disease," The American Journal of Gastroenterology, vol. 102, no. 12, pp. 2754-2761, 2007.

[11] R. L. Roberts, J. E. Hollis-Moffatt, R. B. Gearry, M. A. Kennedy, M. L. Barclay, and T. R. Merriman, "Confirmation of association of IRGM and NCF4 with ileal Crohn's disease in a population-based cohort," Genes \& Immunity, vol. 9, no. 6, pp. 561-565, 2008.

[12] R. B. Gearry, R. L. Roberts, M. J. Burt, et al., "Effect of inflammatory bowel disease classification changes on NOD2 genotype-phenotype associations in a populationbased cohort," Inflammatory Bowel Diseases, vol. 13, no. 10, pp. 1220-1227, 2007.

[13] T. Ozeki, Y. Furuya, C. Nagano, et al., "Analysis of linkage between lymphotoxin $\alpha$ haplotype and polymorphisms in $5^{\prime}$ flanking region of tumor necrosis factor $\alpha$ gene associated with efficacy of infliximab for Crohn's disease patients," Mutation Research/Fundamental and Molecular Mechanisms of Mutagenesis, vol. 602, no. 1-2, pp. 170-174, 2006.
[14] C. P. Beltinger, P. S. White, J. M. Maris, et al., "Physical mapping and genomic structure of the human TNFR2 gene," Genomics, vol. 35, no. 1, pp. 94-100, 1996.

[15] B. B. Aggarwal, "Signalling pathways of the TNF superfamily: a double-edged sword," Nature Reviews Immunology, vol. 3, no. 9, pp. 745-756, 2003.

[16] E. Baker, L. Z. Chen, C. A. Smith, D. F. Callen, R. Goodwin, and G. R. Sutherland, "Chromosomal location of the human tumor necrosis factor receptor genes," Cytogenetics and Cell Genetics, vol. 57, no. 2-3, pp. 117-118, 1991.

[17] O. Kemper, J. Derré, D. Cherif, H. Engelmann, D. Wallach, and R. Berger, "The gene for the type II (p75) tumor necrosis factor receptor (TNF-RII) is localized on band 1p36.2-p36.3," Human Genetics, vol. 87, no. 5, pp. 623-624, 1991.

[18] F. K.-M. Chan, H. J. Chun, L. Zheng, R. M. Siegel, K. L. Bui, and M. J. Lenardo, "A domain in TNF receptors that mediates ligand-independent receptor assembty and signaling," Science, vol. 288, no. 5475, pp. 2351-2354, 2000.

[19] J. H. Cho, D. L. Nicolae, L. H. Gold, et al., "Identification of novel susceptibility loci for inflammatory bowel disease on chromosomes 1p, 3q, and 4q: evidence for epistasis between $1 \mathrm{p}$ and IBD1," Proceedings of the National Academy of Sciences of the United States of America, vol. 95, no. 13, pp. 7502-7507, 1998.

[20] P. Dieudé, E. Petit, S. Cailleau-Moindrault, et al., "Association between tumor necrosis factor receptor II and familial, but not sporadic, rheumatoid arthritis: evidence for genetic heterogeneity," Arthritis \& Rheumatism, vol. 46, no. 8, pp. 2039-2044, 2002.

[21] T. Komata, N. Tsuchiya, M. Matsushita, K. Hagiwara, and K. Tokunaga, "Association of tumor necrosis factor receptor 2 (TNFR2) polymorphism with susceptibility to systemic lupus erythematosus," Tissue Antigens, vol. 53, no. 6, pp. 527-533, 1999.

[22] H. Sashio, K. Tamura, R. Ito, et al., "Polymorphisms of the TNF gene and the TNF receptor superfamily member $1 \mathrm{~B}$ gene are associated with susceptibility to ulcerative colitis and Crohn's disease, respectively," Immunogenetics, vol. 53, no. 12, pp. 1020-1027, 2002.

[23] K. A. Waschke, A.-C. Villani, S. Vermeire, et al., "Tumor necrosis factor receptor gene polymorphisms in Crohn's disease: association with clinical phenotypes," The American Journal of Gastroenterology, vol. 100, no. 5, pp. 1126-1133, 2005.

[24] A. Barton, S. John, W. E. R. Ollier, A. Silman, and J. Worthington, "Association between rheumatoid arthritis and polymorphism of tumor necrosis factor receptor II, but not tumor necrosis factor receptor I, in Caucasians," Arthritis \& Rheumatism, vol. 44, no. 1, pp. 61-65, 2001.

[25] K. M. Tarrant, M. L. Barclay, C. M. A. Frampton, and R. B. Gearry, "Perianal disease predicts changes in Crohn's disease phenotype-results of a population-based study of inflammatory bowel disease phenotype," The American Journal of Gastroenterology, vol. 103, no. 12, pp. 3082-3093, 2008.

[26] M. S. Silverberg, J. Satsangi, T. Ahmad, et al., "Toward an integrated clinical, molecular and serological classification of inflammatory bowel disease: Report of a Working Party of the 2005 Montreal World Congress of Gastroenterology," Canadian Journal of Gastroenterology, vol. 19, supplement A, pp. 5-36, 2005.

[27] M. J. Burt, P. M. George, J. D. Upton, et al., "The significance of haemochromatosis gene mutations in the general population: implications for screening," Gut, vol. 43, no. 6, pp. 830-836, 1998. 
[28] R. Ihaka and R. Gentleman, "R: a language for data analysis and graphics," Journal of Computational and Graphical Statistics, vol. 5, no. 3, pp. 299-314, 1996.

[29] T. J. Schall, M. Lewis, K. J. Koller, et al., "Molecular cloning and expression of a receptor for human tumor necrosis factor," Cell, vol. 61, no. 2, pp. 631-370, 1990.

[30] C. Morita, T. Horiuchi, H. Tsukamoto, et al., "Association of tumor necrosis factor receptor type II polymorphism 196R with systemic lupus erythematosus in the Japanese molecular and functional analysis," Arthritis \& Rheumatism, vol. 44, no. 12, pp. 2819-2827, 2001.

[31] A. Kawasaki, N. Tsuchiya, K. Hagiwara, M. Takazoe, and K. Tokunaga, "Independent contribution of HLA-DRB1 and $\mathrm{TNF} \alpha$ promoter polymorphisms to the susceptibility to Crohn's disease," Genes \& Immunity, vol. 1, no. 6, pp. 351-357, 2000.

[32] H. Matsukura, S. Ikeda, N. Yoshimura, M. Takazoe, and M. Muramatsu, "Genetic polymorphisms of tumour necrosis factor receptor superfamily $1 A$ and $1 B$ affect responses to infliximab in Japanese patients with Crohn's disease," Alimentary Pharmacology \& Therapeutics, vol. 27, no. 9, pp. 765-770, 2008. 


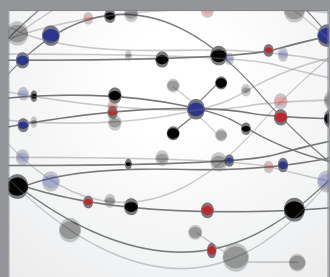

The Scientific World Journal
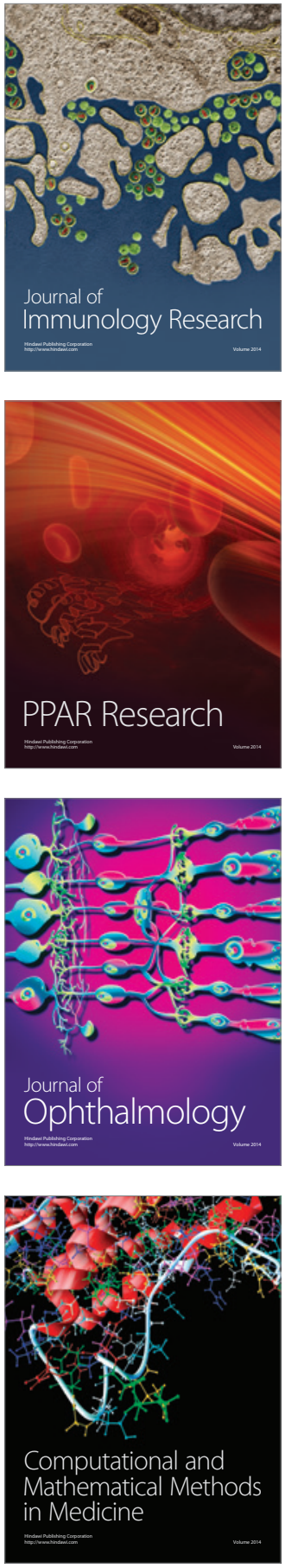

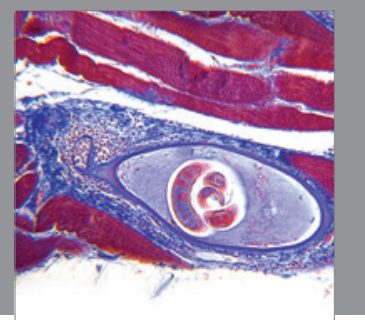

Gastroenterology

Research and Practice
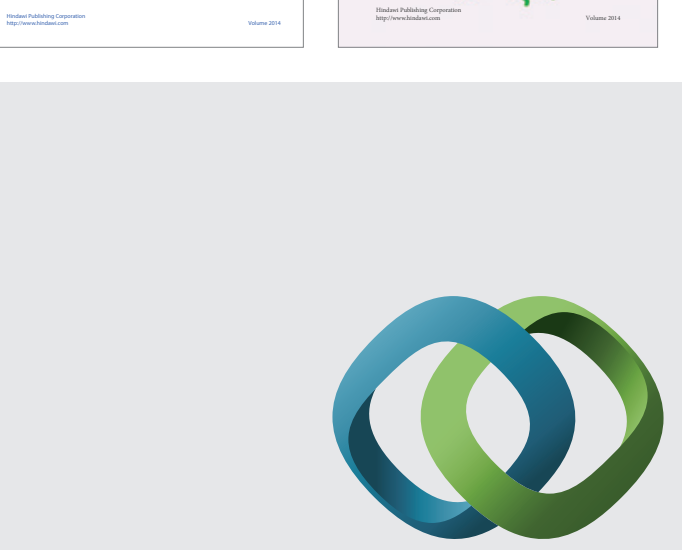

\section{Hindawi}

Submit your manuscripts at

http://www.hindawi.com
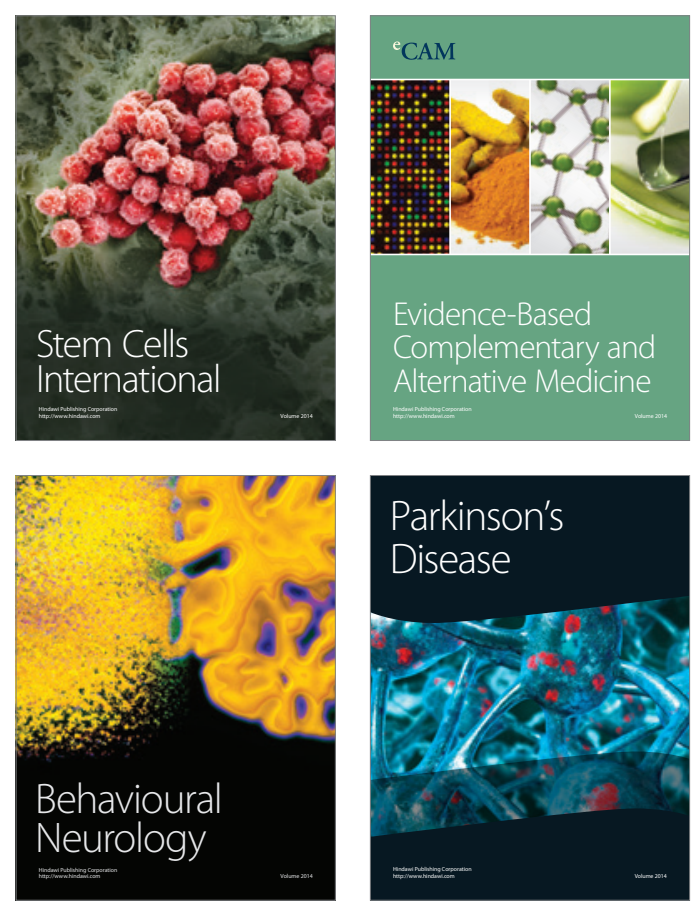

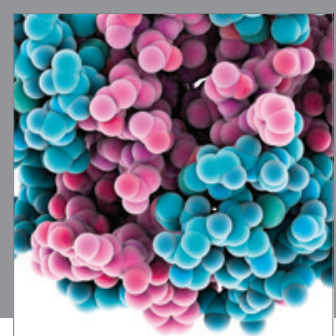

Journal of
Diabetes Research

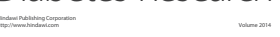

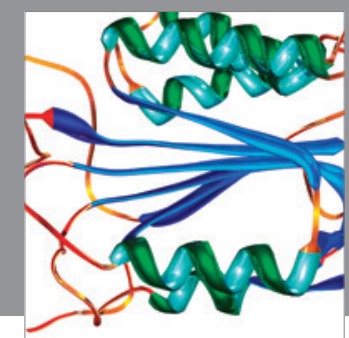

Disease Markers
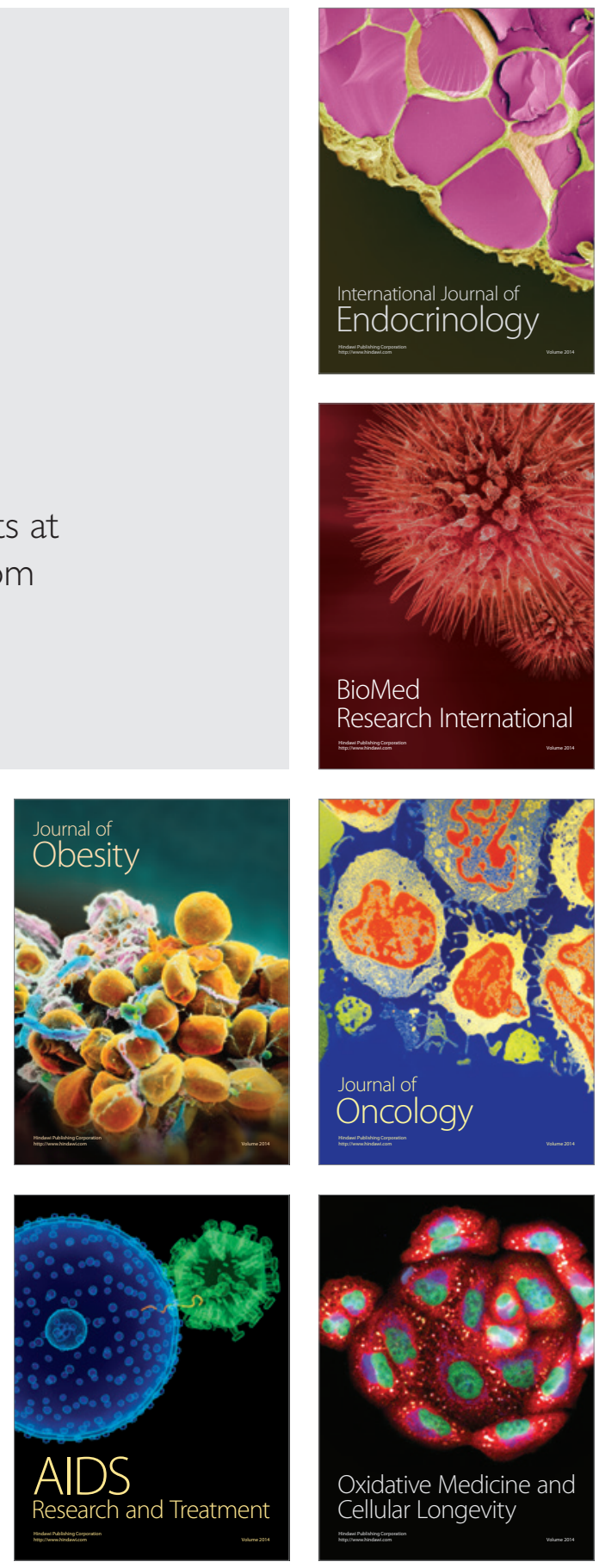